\title{
Soviet scientists visit UK and 'sell' technology
}

"SCIENCE is universal because it strives after universal truths that can be universally verified. Scientists have no option therefore but to collaborate and have done so successfully even when political relations are bad. But technology is different; because it is 'sensitive'."

So said Professor J. Ashworth, Senior Scientific Adviser to the Cabinet Office at the opening last week of the "Days of Soviet Science and Technology" organised in association with the USSR National Exhibition at Earl's Court, London. By this criterion, it might be deduced, both from the exhibition itself and from the composition of the scientific "touring team", that détente is alive and flourishing. For both are strongly orientated towards technology.

For the exhibition, this may be inevitable; a Soyuz space-capsule or nonpolluting oil refinery is much easier to demonstrate to the public than the latest developments in quantum mechanics. Even the announced "massive" participation of the Soviet Academy of Sciences, apart of course for the baby mammoth, reduces to a few technological exhibits-some special industrial alloys, a method of shaping high-precision tools from graphite and then converting them to diamond, and a laser landing system for aircraft which, Academician Basov, the leader of the scientific delegation urged, would be particularly suitable in the British climate.

Basov, who holds a Nobel Prize in physics for his work on lasers, has become, in the context of this tour, virtually a salesman for Soviet laser technology. Even addressing the Royal Society, his subject matter was more practical than theoretical-laser welding, laser precision systems for wire manufacture, laser coagulation for eyesurgery, a laser-based 2,000-line TV set in the "nearest future", as well as the prospects of lasers in the $10^{5}-10^{8} \mathrm{~J}$ range and a "very promising" hybrid reactor with a "thermonuclear target surrounded by fissile material". The main problem with the latter, he said, will be the "service life but ideologically we are prepared for further developments".

Equaly a "salesman" but with longer aims in view is Professor Andrei Kapitsa, whose speciality is remote sensing from space. This he sees as a major field of potential cooperation, particularly in "global problems" such as pollution. "Even a country as large as the Soviet Union cannot save the problem of air pollution", he said. "This can only be done on an international basis." Then, too, there are problems of induced climatic change.
A major irrigation or rain-making initiative by one country could have disastrous consequences for another, if there is no international consultation. According to Kapitsa, however, Soviet planners "don't yet use space data directly, but only at the second or third remove." Science, he said, "is always two steps ahead, giving the economy a tug!"

The "Days of Soviet Science and Technology" are presumably designed to give a similar "tug" to BritishSoviet economic cooperation. "Econmic cooperation goes very closely with such things as know-how", Kapitsa explained. "Know-how is sold, and knowhow is science".

Several members of the delegation, however, saw the "Days" rather as a useful chance of pursuing their own research. The three Medical Academicians, Kochetkov, Loginov and Puchkovskaya all spoke in terms of existing cooperation. So did Academician I. M. Kolotryrkin, who explained that in his particular field-metal corrosion - the UK and USSR have already achieved a de facto division of labour. "Britain is doing some very interesting work on the metallurgical side", he said, "stress corrosion, cracking and so on. In the Soviet Union we use mainly a chemical and radiochemical approach. This is a genuine sharing of effort".

For Professor F. V. Sapozhnikov, however, diverging priorities between the UK and the USSR might well have made fruitful discussions difficult. For as Deputy Minister of Power and Electrification, he is committed to a major nuclear power programme, which includes not only power generation, but even the production of hot water for district heating from small reactors sited on the outskirts of cities. (It is considered sufficient for

safety if a zone $3 \mathrm{~km}$ in radius round the reactor is kept free from residential use, although it may be used for agriculture, industry or leisure purposes).

The commitment to nuclear energy was well represented at Earl's Court; exhibits included a scale model of the BN-600 water-water reactor intended for the third set of the Beloyarsk power station and a diorama of the South Ukrainian power complex, which will be based on $4 \times 1,000 \mathrm{MW}$ nuclear generating sets, with a $1,800 \mathrm{MW}$ hydroelecrtic auxiliary plant for peak hours and a $380 \mathrm{MW}$ pumped storage system.

Sapozhnikov did not see Britain's current disenchantment with nuclear power as any barrier to cooperation. "We pay a great deal of attention to UK experience", he said. "We have enjoyed a good cooperation programme for several years now, and it has worked quite successfully".

Such remonstrances have in general been fairly infrequent. Apart from the constant stress that exchange benefits the UK as much as it does the Soviet Union, there has been little emphasis on "misunderstandings" and much on mutual benefits and the building of what Basov called "a bridge of confidence" between Soviet and British scientists.

"Our main task is to learn what others have done and to show what we have done", Basov explained. Then, doubtless not unaware of the posse of demonstrators who had dogged the delegation with their banners demanding the release of Orlov, Shcharanskii and Kovalev, he added, "We respect and treat with understanding the customs of your country. As the Russian proverb says 'When you arrive at a strange monastery, don't try to induce your own rules there';"

Vera Rich

\section{Soviet progress in wind and solar power}

SovieT solar energy enthusiasts may one day give a new meaning to the term industrial plant. Recently Dimitri Zhimerin, Deputy Chairman of the USSR State Committee for Science and Technology, said that "scientists believe that solar energy could be used for industrial applications if generators were developed imitating photosynthesis". So far, however, no-one has announced artificial photosynthesis as a viable method.

Zhimerin's statement, however, came in an otherwise factual account of research into solar and wind power in the Central Asian Steppes. In addition to solar heating for domestic use considerable progress, he said, has been made in water desalination for state cattle farms. Here the breakeven point occurs when water would otherwise have to travel $35-40 \mathrm{~km}$.

Extensive use of solar energy in these regions could, he said, save the Soviet economy 15-20 million tonnes of conventional fuel per year while wind energy, properly exploited, could produce $11 \times 10^{6} \mathrm{MW}, 50$ times the total capacity of all Soviet power stations in 1976. According to Zhimerin, the first wind powered electrical generator with a capacity of $100 \mathrm{~kW}$ was built in the Soviet Union in 1930. The experience gained with it has led to the development of "wind powered units, both mechanical and electrical". 